\title{
Making Edible Film from Jackfruit Seed Starch (Artocarpus Heterophyllus) with the Addition of Rosella Flower Extract (Hibiscus Sabdariffa L.) as Antioxidant
}

\author{
Purnama Ningsih*, Sitti Rahmawati, Ni Made Nila Santi, Suherman, Anang Wahid M. Diah \\ Department of Mathematics and Natural Sciences Education, Faculty of Teacher Training and Education, Tadulako University, \\ Palu City 94118, Indonesia
}

Corresponding Author Email: purnama_ningsih@untad.ac.id

https://doi.org/10.18280/ijdne.160611

Received: 11 September 2021

Accepted: 19 November 2021

\section{Keywords:}

edible film, jackfruit seed starch, rosella flower extract, glycerol, plasticizer

\begin{abstract}
This study aims to determine the physical and chemical characteristics of the edible film of jackfruit seed starch (Artocarpus heterophyllus) added with antioxidant rosella flower extract (Hibiscus sabdariffa). The type of plasticizer used is glycerol. The best treatment in this study was the jackfruit seed edible film with the addition of rosella flower extract $3 \%(\mathrm{v} / \mathrm{v})$ with the results obtained respectively for a thickness of $0.09 \mathrm{~mm}$, tensile strength $0.003332 \mathrm{~N} / \mathrm{mm}^{2}$, elongation percentage $126.36 \%$, elasticity 0.002637 $\mathrm{Kgf} / \mathrm{mm}^{2}$, pH 6.122, water absorption $61.67 \%$, solubility $40 \%$, water vapor transmission speed 0.6714 gram/hour $\mathrm{m}^{2}$, FTIR test results show that the process of making edible film in this research is the mixing process Physics, the shelf life of edible film at room temperature is 6 days and at cold temperatures is 8 days, and has antioxidant activity with an $\mathrm{IC}_{50}$ value $219.948 \mathrm{ppm}$. The addition of rosella flower extract enhances another benefit of edible film which functions as a food protector from the oxidation process (antioxidant).
\end{abstract}

\section{INTRODUCTION}

Food ingredients are generally vulnerable to damage and decrease in quality, especially those with high protein content and water content. Both of these contents will support the growth of bacteria that can damage the quality and nutritional content of foodstuffs [1]. With packaging, food will be protected from contamination from outside, including ensuring food safety, maintaining quality and increasing shelf life. Plastic is the most commonly used food packaging material, because it is flexible, light, economical, not easily broken, and strong [2]. However, plastic can contaminate packaged foodstuffs due to the presence of substances such as bisphenol-A (BPA), phthalates and other harmful compounds that are potential carcinogens (cancer-inducing substances) [3]. In addition, plastic is non-biodegradable (cannot decompose naturally), so it can pollute the environment [4].

Many ways are used to overcome this problem, one of which is developing environmentally friendly food packaging. Edible film is used as an alternative as an environmentally friendly packaging material because it can be decomposed by microorganisms (biodegradable) and can be eaten (edible) so it does not pollute the environment [5]. Edible films can be made from hydrocolloids and fats or a mixture of both. Starch is a basic material that is often used, because it has several advantages such as being good at protecting products against oxygen, carbon dioxide and lipids, as well as having the desired mechanical properties [6]. Starch comes from plants, both from the stem, fruit, roots and tubers. One of the plants that can be a source of starch is jackfruit seeds.

Jackfruit is one of the plants that has many benefits, this plant is widely found in Indonesia and produces fruit almost all year round. The edible flesh of jackfruit is only $20-31 \%$, the skin is $55-70 \%$ and the seeds are about $5-15 \%$. Generally, jackfruit seeds are consumed in the form of boiled or roasted, but most of the jackfruit seeds are discarded, even though jackfruit seeds have the potential as a source of carbohydrates, protein and energy. Judging from its chemical composition, jackfruit seeds contain quite high starch, which is around 40$50 \%$, so it has the potential to be used as edible film (food packaging) [7, 8].

Apart from acting as packaging for foodstuffs, Edible films can also function as carriers of antioxidant compounds that are able to delay, slow down and prevent oxidation of packaged foods. Antioxidant compounds can be obtained from the extraction of natural materials such as plants [9]. One source of natural antioxidants is rosella flowers. Rosella is a plant that produces edible red flower petals, where the red color of rosella flowers is caused by the anthocyanin content. Anthocyanins are flavonoid group compounds that have the ability as antioxidants [10]. Based on the antioxidant activity test using the DPPH (1,1-diphenyl-2-picryl hydrazil) method, it showed that rosella flower extract had antioxidant activity with an IC50 value of $33.79 \mathrm{~g} / \mathrm{ml}$ and was safe to use as a food additive [11].

Research on edible films with starch-based ingredients has been widely carried out, including the manufacture of edible films from the starch of durian seeds (Durio zhibethinus) using glycerol and sorbitol stabilizer. The characterization results showed the best durian seed starch edible film with the addition of $2.5 \%(\mathrm{w} / \mathrm{v})$ glycerol and $2 \%(\mathrm{w} / \mathrm{v})$ plasticizer for sorbitol. The shelf life of edible films at room temperature is 5 days and at cold temperatures for 7 days [12]. Another type of starch that can be used as an edible film is the Banggai Tuber (Dioscorea Spp). The best results were obtained by using a temperature of $80^{\circ} \mathrm{C}$ and $2 \%(\mathrm{w} / \mathrm{v})$ glycerol and $2 \%(\mathrm{w} / \mathrm{v})$ 
sorbitol. The shelf life of edible films at room temperature is 6 days and at cold temperatures is 8 days [13].

Another edible film research is the addition of soursop leaf extract (Annona muricata L.) as an anti-oxidant in edible films from durian starch (Durio zibethinus). The results obtained from the physical characteristics of edible film seen from the water vapor transmission test have met the JIS 1975 standard, which is a maximum of $10 \mathrm{~g} / \mathrm{m} 2.24$ hours. Chemical characteristics of edible films which include water content testing, all edible films with the addition of soursop leaf extract have met the SNI standard, which is below 20\%. While in the antioxidant test the IC50 value which shows the highest antioxidant activity in edible films with the addition of $2 \mathrm{~g}$ soursop leaf extract is $1.5875 \mathrm{mg} / \mathrm{mL}$ [14].

Previous research on starch from jackfruit seeds as an ingredient for making edible films with variations in the addition of starch and variations in plasticizers has also been carried out. The best treatment was obtained with the use of $3 \%$ starch with the addition of $1 \%(\mathrm{w} / \mathrm{v})$ glycerol plasticizer. The results obtained are for thickness $0.24 \mathrm{~mm}$, tensile strength $8.35 \times 10^{-5} \mathrm{~N} / \mathrm{mm}^{2}$, elongation $49.19 \%$, elasticity $1.69 \times 10^{-5}$ $\mathrm{Kgf} / \mathrm{mm}^{2}$, pH 7.024, absorption $75 \%$ water vapor transmission $0.00908 \mathrm{~g} /$ hour. $^{2}$, the biodegradability test showed that the edible film in this study degraded within 5 days, the FTIR test results showed that the process of making edible film in this study was a physical mixing process and the shelf life of edible film with potato wrapper on room temperature is 4 days. and at cold temperatures for 6 days [15].

Based on the literature search and the research above, it shows that there has been no research on the characteristics of the edible film of jackfruit seed starch with the addition of rosella flower extract as an antioxidant. As a result, researchers are interested in studying the features of the edible films of jackfruit seed starch utilizing rosella flower extract.

\section{METHODS}

\subsection{Making jackfruit seed starch}

Jackfruit seeds as much as $2 \mathrm{~kg}$ peeled from the skin and cleaned. Jackfruit seeds were cut into small pieces and cleaned with distilled water, then blended at low speed by adding a $0.0230 \%$ sodium bisulfite solution (2.3 grams of sodium bisulfite and 2 liters of aquadest). Then squeezed using a fine porous cloth until no more juice. The resulting pulp is discarded and the juice is left for 24 hours. The precipitate obtained from the stand was washed with distilled water and filtered through a Bucher filter. The clean precipitate was dried in an oven for 12 hours at $50^{\circ} \mathrm{C}$. The dried precipitate was blended or ground, then sieved with a 100 mesh sieve, to obtain jackfruit seed starch [3].

\subsection{Preparation of rosella flower extract}

Dried rosella flowers were blended and sieved to obtain rosella flower powder. Next, weigh 5 grams of rosella flower powder and then put it in an Erlenmeyer. Then add $100 \mathrm{~mL}$ of a mixture of ethanol and water solvents (ratio 50: 50). Erlenmeyer was covered with aluminum foil and macerated at room temperature $\pm 25^{\circ} \mathrm{C}$ for 24 hours. The maceration results were filtered using filter paper, so that the rosella flower filtrate was obtained [16-18]. The filtered filtrate was concentrated with a rotary evaporator [19].

\subsection{Making edible film}

Jackfruit seed starch is weighed as much as 3 grams, then put into a beaker. Then add $2 \%(\mathrm{w} / \mathrm{v})$ glycerol solution and rosella extract with extract variations of $1.5 \%, 2.0 \%, 2.5 \%$, $3 \%(\mathrm{v} / \mathrm{v})$. The solution was heated on a hot plate with a mixture of $80 \mathrm{~mL}$ of distilled water at $80^{\circ} \mathrm{C}$ for 15 minutes with a magnetic stirrer. Then add 1 gram of $\mathrm{CMC}$ with $20 \mathrm{~mL}$ of distilled water and reheat at $80^{\circ} \mathrm{C}$ for 7 minutes. The solution was poured into $25 \times 20 \times 2 \mathrm{~cm}$ mold and dried in an oven at $50^{\circ} \mathrm{C}$ for 18 hours. The mold that comes out of the oven is cooled at room temperature for 10 minutes. The skin layer formed was peeled off with the help of a spatula and inserted or stored in a desiccator [20].

\subsection{Physical and chemical characterization of edible film}

\subsubsection{Thickness test}

Thickness of the edible film was measured using a micrometer at 5 different places with an accuracy of $0.01 \mathrm{~mm}$. The measurement results are averaged as a result of the film thickness. Measurements were made on the resulting 4 samples [21].

\subsubsection{Tensile strength, elongation and elasticity test}

Tensile strength is the maximum force that an edible film can until it breaks. Percent elongation is the maximum elongation change that can be experienced by the edible film when it is stretched or stretched until before the edible film breaks. Tensile strength, the test was carried out by means of an edible film attached to the top and bottom grids. The value on the recorder is zeroed, the test is started by pressing the UP button. Press the RETURN button to return the grip to its original position. The sample size used for this test is $8 \times 4 \mathrm{~cm}$ $(80 \mathrm{~mm} \times 40 \mathrm{~mm}$ ) with a tensile speed of $700 \mathrm{~mm} / \mathrm{min}$, grip weight $=50 \mathrm{~N} / 5 \mathrm{Kgf}$, sample area $(\mathrm{A})=(80 \times 40) \mathrm{mm}^{2}$ [22]

$$
\text { Tensile strength }\left(\mathrm{N} / \mathrm{mm}^{2}\right)=\frac{F \max }{A}
$$

where:

$\mathrm{F}$ max $=$ sample tensile value $(\mathrm{N})$;

$\mathrm{A}=$ sample area $\left(\mathrm{mm}^{2}\right)$.

Elongation is used to see the maximum length of the edible film before breaking in the tensile strength test. The elongation of the sample is read automatically in the form of the difference in film elongation $=\mathrm{L}(\mathrm{mm})[22]$.

$$
\% \text { Elongation }=\frac{\mathrm{L}}{\mathrm{Lo}} \times 100 \%
$$

where:

$\mathrm{L}=$ Difference in film elongation;

$\mathrm{L}_{\mathrm{o}}=$ Initial length of film

As for elasticity, it is obtained from the comparison between tensile strength and elongation [23].

\subsubsection{Functional group analysis with FTIR}

Functional Group Analysis with FTIR aims to determine the process that occurs in the mixing whether physically or chemically, therefore the samples in each process of making edible film are analyzed by FTIR. The sample is placed into the set holder, then the appropriate spectrum is searched. The 
results will be obtained in the fractogram of the relationship between wave number and intensity. The FTIR spectra were recorded using a spectrophotometer at room temperature [24].

\subsection{4 $\mathrm{pH}$ test}

This examination is carried out using a $\mathrm{pH}$ meter. The $\mathrm{pH}$ measurement was carried out by dissolving 1 gram of edible film in $10 \mathrm{~mL}$ of distilled water in a petri dish. The electrode is dipped into a cup containing an edible film solution and then the number indicated by the $\mathrm{pH}$ meter is seen. Do it on each sample [22].

\subsubsection{Biodegradability test}

Biodegradation test (ability of bioplastics to decompose) was carried out by immersing edible film samples into EM4 (Effective Microorganism 4). The EM4 bacteria used are bacteria for the fermentation of soil organic matter. EM4 contains fermenting bacteria of the genus Lactobacillus, fermenting fungi, photosynthetic bacterial actinomycetes, phosphate solubilizing bacteria, and yeasts [25].

\subsubsection{Water absorption test}

The water absorption test of edible film was carried out by weighing 2 grams of the edible film sample, then weighing it as the initial weight (D), then dipped into a container containing distilled water for 10 seconds then the sample was removed from the container and the water was poured. still attached to the surface of the edible film was removed using a tissue, then weighed to obtain the final weight of the sample (C). The immersion and weighing procedures were carried out continuously until the final sample weight was constant [26].

$$
\% \text { Water Absorption }=\frac{C D}{D} \times 100 \%
$$

where:

$\mathrm{C}=$ Final weight;

$\mathrm{D}=$ Initial weight.

\subsubsection{Solubility test}

Solubility test was carried out by weighing 2 grams of edible film sample, then put it in the oven using a cup at a temperature of $100^{\circ} \mathrm{C}$ for 30 minutes. Furthermore, the film is weighed as the initial weight (B), then the edible film is soaked for 24 hours, the insoluble film is removed and dried in an oven for 2 hours at a temperature of $100^{\circ} \mathrm{C}$. The film was taken and put in a desiccator for 10 minutes. Then it was weighed again to get the weight of the dry edible film after soaking (D) [27].

$$
\% \text { Solubility of film }=\frac{\mathrm{BD}}{\mathrm{B}} \times 100 \%
$$

where:

B = Weight before immersion;

D $\quad=$ Weight after immersion.

\subsubsection{Water vapor transmission rate}

The water vapor transmission rate to the edible film was measured using a porcelain cup. Before being measured, the room in the desiccator was conditioned at humidity which had a RH of $75 \%$ by adding $40 \% \mathrm{NaCl}$ salt solution. In a porcelain dish, put 5 grams of activated silica gel and 3 grams of edible film placed in a porcelain cup and sealed in such a way that there are no gaps at the edges. Furthermore, the porcelain dish was weighed with an accuracy of 0.0001 grams and then placed in a desiccator that had been conditioned, then tightly closed. Every hour for 5 hours the porcelain cup is determined the value of the water vapor transmission rate [28].

$$
\mathrm{WvTR}=\frac{\mathrm{Mv}}{\mathrm{tA}}
$$

where:

$\mathrm{Mv}=$ Addition/reduction of water vapor mass (grams);

$\mathrm{t} \quad=$ weighing period (hours);

A $=$ area of edible film tested $\left(\mathrm{cm}^{2}\right)$.

\subsubsection{Shelf life test}

The shelf life test is determined by the acceleration method. This test was carried out after knowing the optimum composition in the manufacture of edible films. Plastic edible film is then applied to wrap the potatoes which have been prepared in accordance with the treatment, the first treatment that is safe in an open space $\left(30^{\circ} \mathrm{C}\right)$ there are 3 variations of packaging: $\mathrm{K}_{1}$ (without packaging), $\mathrm{K}_{2}$ (wrapped edible film), and $\mathrm{K}_{3}$ (wrapped in parchment paper). The second treatment is storage in a cold room $\left(16^{\circ} \mathrm{C}\right)$ there are 2 variations of packaging: $\mathrm{K}_{0}$ (without packaging) and $\mathrm{K}_{1}$ (wrapped in edible film) [29].

\subsubsection{Analysis of antioxidant activity with DPPH method}

The antioxidant activity of the concentrated extract of the sample was determined using the spectrophotometric method with DPPH reagent. The sample extract was weighed as much as $10 \mathrm{mg}$ and then put into a $10 \mathrm{~mL}$ volumetric flask, then adjusted with ethanol solvent to obtain a solution concentration of $1000 \mathrm{ppm}$. Then a series of dilutions were carried out to obtain solutions of 20, 40, 60, 80 and $100 \mathrm{ppm}$. The solution that has been made is pipette as much as $1 \mathrm{~mL}$ and added with $3 \mathrm{~mL}$ of $50 \mu \mathrm{M}$ DPPH solution. The mixture was homogenized and left for 30 minutes in a dark place. Then the absorption was measured at a wavelength of $517 \mathrm{~nm}$. Tests were also carried out on the DPPH solution. The absorbance value obtained was used to determine the $\%$ inhibition using the following equation.

$$
\% \text { Inhibition }=\frac{\text { Abs blank }- \text { Abs sample }}{\text { Abs blank }} \times 100 \%
$$

where:

Abs. Blank = DPPH Absorbance $50 \mu \mathrm{M}$;

Abs. Sample $=$ Absorbance Test Sample.

Then the $\%$ inhibition curve was made and $\mathrm{IC}_{50}$ determined based on the obtained regression equation [30].

\section{RESULTS \& DISCUSSIONS}

\subsection{Edible film of jackfruit seed starch with the addition of rosella flower extract}

Jackfruit seed starch is the essential ingredient of making the edible film which is obtained by processing ripe jackfruit seeds through several stages to form jackfruit seed powder. Jackfruit seed starch is in powder form and yellowish white in color (Figure 1). In addition to jackfruit seed starch, another ingredient used is rosella flower extract. Rosella flower extract was obtained using the maceration method of ethanol and 
aquadest in a ratio of 50:50(v/v). The red rosella flower extract can be seen in Figure 1.

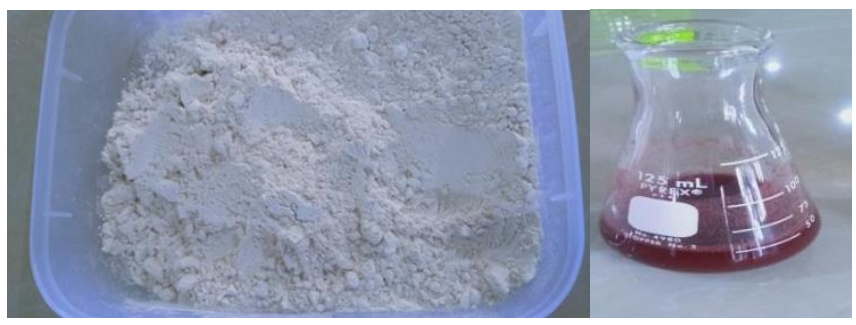

Figure 1. Jackfruit starch and rosella flower extract

Edible film from jackfruit seed starch was made by adding rosella flower extract with 4 variations, namely $1.5 \%(\mathrm{G} 1) ; 2 \%$ (G2); $2.5 \%(\mathrm{G} 3) ; 3 \%(\mathrm{G} 4)(\mathrm{v} / \mathrm{v})$ can be seen in Figure 2.

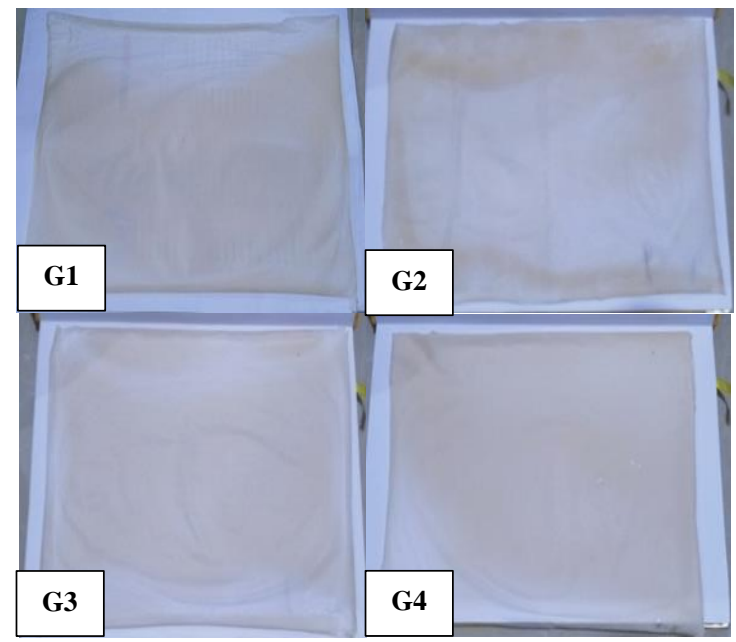

Figure 2. Jackfruit seed starch edible film with addition of rosella extract

\subsection{Physical and chemical characterization of edible film}

\subsubsection{Thickness test}

The thickness of the edible film was measured using a screw micrometer with an accuracy of $0.01 \mathrm{~mm}$ at 5 different points, namely the part of each corner and the middle of the edible film. The measurement results are then averaged so that the thickness value is obtained which can be seen in Table 1 .

Results in Table 1 show that the addition of rosella flower extract with concentrations of $1.5 \%, 2 \%, 2.5 \%$ and $3 \%(\mathrm{v} / \mathrm{v})$ produces edible films with different thicknesses. This difference in thickness can be influenced by an uneven film print, resulting in a buildup of excess solution on several sides and after drying, a film with different thicknesses on each side is obtained. In addition to the amount of solids, other factors that affect the thickness are the type of raw material, the amount of solids, the volume of the solution and the area of the mold [31]. The addition of rosella flower extract did not affect the thickness of the edible film produced. This is because the added rosella flower is already in the form of an extract so that it does not add a large total solid.

The edible film produced in this study was thinner than the edible film of jackfruit seed starch without the addition of extracts ranging from 0.21-0.24 mm [16]. However, it has met the standard thickness of edible film according to the Japanese Industrial Standard (1975), which has a maximum thickness of $0.25 \mathrm{~mm}$. Thickness is a physical property that will determine other properties such as tensile strength, elongation and the ability to withstand water vapor transmission (permeability). The thicker the edible film, the tighter the structure, the stronger the ability to withstand gas migration and protect the product from physical damage [32].

Table 1. Physical and chemical characterization of edible film

\begin{tabular}{|c|c|c|c|c|}
\hline \multirow{2}{*}{ Parameters } & \multicolumn{4}{|c|}{ Treatments } \\
\hline & G1 & $\mathrm{G} 2$ & G3 & G4 \\
\hline Thickness (mm) & 0.11 & 0.14 & 0.07 & 0.09 \\
\hline Tensile strength & 4.11 & 5.32 & 3.21 & 3.33 \\
\hline$\left(\mathrm{N} \cdot \mathrm{mm}^{-2}\right)$ & $\times 10^{-3}$ & $\mathrm{x} 10^{-3}$ & $\mathrm{x} 10^{-3}$ & $\times 10^{-3}$ \\
\hline Elongation (\%) & 101.53 & 112.65 & 126.15 & 126.36 \\
\hline Elasticity & 4.05 & 4.72 & 2.54 & 2.64 \\
\hline$($ Kgf.mm²) & $\mathrm{x} 10^{-3}$ & $\mathrm{x} 10^{-3}$ & $\mathrm{x} 10^{-3}$ & $\times 10^{-3}$ \\
\hline $\mathrm{pH}$ & 6,222 & 6,239 & 5,724 & 6,122 \\
\hline $\begin{array}{c}\text { Water Absorption } \\
(\%)\end{array}$ & 80 & 70 & 60 & 61.67 \\
\hline Solubility (\%) & 100 & 41.67 & 17.65 & 40 \\
\hline $\begin{array}{c}\text { WVTR } \\
\left(\text { gram.hour }{ }^{-1} \cdot \mathrm{m}^{-2}\right)\end{array}$ & 0.6356 & 0.61304 & 0.6714 & 0.6775 \\
\hline
\end{tabular}

\subsubsection{Tensile strength, elongation and elasticity test}

Tensile strength is the maximum force that the edible film can withstand until it breaks [22]. The results of the tensile strength test of edible film can be seen in Table 1 .

The results in Figure 4 show that the tensile strength value of edible film with the addition of rosella flower extract is $1.5 \%, 2 \%, 2.5 \%$ and $3 \%(\mathrm{v} / \mathrm{v})$ obtained different results, respectively, namely $4.109 \times 10^{-3} \mathrm{~N} / \mathrm{mm}^{2}, 5.322 \times 10^{-3} \mathrm{~N} / \mathrm{mm}^{2}$, $3.208 \times 10^{-3} \mathrm{~N} / \mathrm{mm}^{2}$, and $3.332 \times 10^{-3} \mathrm{~N} / \mathrm{mm}^{2}$. With the addition of $2 \%(\mathrm{v} / \mathrm{v})$ extract, the best tensile strength value was obtained. This indicates that the tensile strength value is influenced by the thickness of the edible film, where the greater the thickness of the edible film, the higher the tensile strength of the film due to the stronger intramolecular interactions [32].

Edible in this study had a higher tensile strength than the edible film of jackfruit seed starch without the addition of rosella flower extract which had a tensile strength of $8.35 \mathrm{x}$ $10^{-5} \mathrm{~N} / \mathrm{mm}^{2}$ [16]. Based on this, the addition of rosella flower extract can increase the tensile strength value of edibles. Phenolic compounds from rosella flowers can interact to form glycoside bonds with sugar molecules and form hydrogen bonds with protein molecules from the material thereby increasing intramolecular bonds in the polymer film [18]. Tensile strength is a property related to the strength of the film to withstand physical damage, the higher the tensile strength is expected to reduce the maximum damage to the product to be packaged [32].

Elongation is the percentage change in the film's length calculated when the film is stretched to break [21]. The results of the elongation test can be seen in Table 1 .

The results in Table 1 show that the elongation value of the edible film increases with the addition of rosella flower extract concentration, where the elongation value obtained is $101.53 \%$, respectively. $112.65 \%, 126.15 \%$ and $126.36 \%$. The best elongation was obtained at the addition of $3 \%$ extract. The edible film in this study had a greater elongation value than the edible starch of jackfruit seeds without the addition of rosella flower extract which had an elongation of $49.19 \%$ [16].

Factors that can affect elongation are the composition and composition of edible film raw materials [21]. The addition of rosella flower extract can replace the bonds between starch 
polymers during film formation, thereby reducing the stiffness of the edible film. In addition, the addition of glycerol as a platicizer can reduce intermolecular forces and increase the mobility of the biopolymer so that the resulting edible film is more flexible $[24,33]$. The resulting edible film has met the standard elongation value according to the Japanese Industrial Standard (1975), which has a minimum elongation value of $70 \%$ [20].

Elasticity measures the stiffness of a polymer material [26]. Elasticity test results are shown in Table 1 . The results in Table 1 show that adding Rosella flower extract with concentrations of $1.5 \%, 2 \%, 2.5 \%$, and $3 \%(\mathrm{v} / \mathrm{v})$ produced edible films with different elasticity values. The best elasticity was obtained with the addition of $2.5 \%(\mathrm{v} / \mathrm{v})$ extract, seen from the smaller stiffness or elasticity value of the edible film [25]. The edible film in this study has a higher elasticity value than the edible starch of jackfruit seeds without the addition of rosella flower extract which has an elasticity value of $5.87 \times 10^{-5} \mathrm{Kgf} / \mathrm{mm}^{2}$ [16]. This indicates that the addition of rosella extract can increase the stiffness of the edible film.

\subsubsection{Functional group analysis with FTIR}

Functional group analysis using FTIR aims to identify the functional groups contained in the edible film so that it can be seen whether there are new functional groups or not in the formed edible film [26]. The results of the FTIR analysis of the jackfruit seed starch edible film with the addition of rosella flower extract can be seen in Figure 3.

Based on Figure 3, the interpretation of the spectrum can be seen in Table 2. The results of the identification of functional groups in Table 2 show that the edible film of jackfruit seed starch with the addition of rosella flower extract has the same functional group as jackfruit seed starch. This indicates that the addition of rosella flower extract to the edible film does not form new functional groups, so it is a physical mixing with hydrogen interactions between chains. Hydrogen bonding occurs when an atomic molecule contained in glycerol interacts with hydrogen from jackfruit seed starch, rosella flower extract and CMC. The increase in hydrogen bonding can be seen from the increase in the $\mathrm{OH}$ functional group on the edible film [13]. The increased hydrogen bonding makes the edible film denser and stiffer. Stiffness can be reduced by adding glycerol so that the edible film formed is more elastic [26].

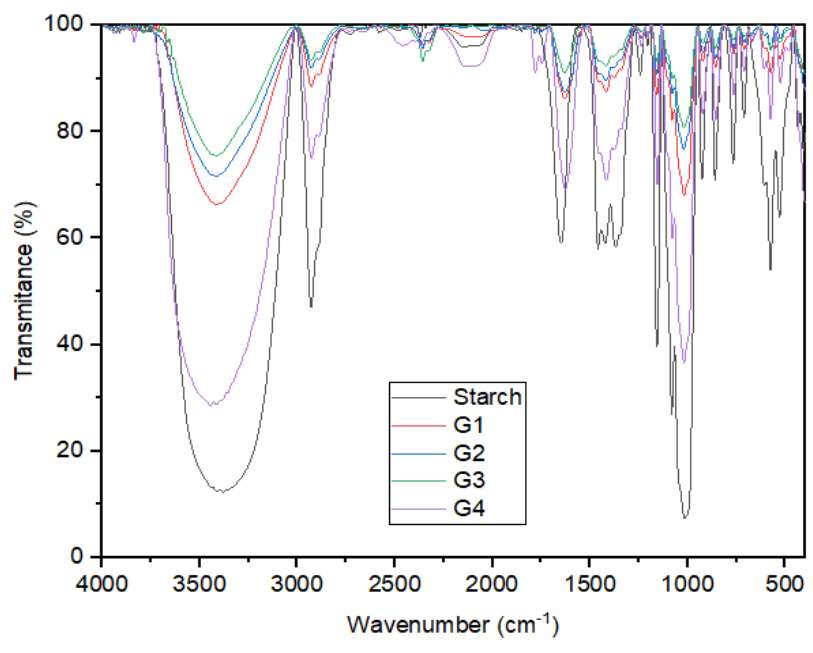

Figure 3. FTIR edible film spectrum

Table 2. Interpretation of FTIR edible film spectrum

\begin{tabular}{ccccccc}
\hline \multirow{2}{*}{ Functional Groups } & \multirow{2}{*}{ Regional Frequency $\left(\mathbf{c m}^{-1}\right)[\mathbf{3 4}]$} & Starch & G1 & G2 & G3 & G4 \\
\hline \multirow{2}{*}{ CH Alkanes } & $2850-2970$ & 2929.87 & 2929.87 & 2927.94 & 2929.87 & 2927.94 \\
& $1340-1470$ & 1421,54 & 1417.68 & 1417.68 & 1417.68 & 1417.68 \\
CH Alkenes & $675-995$ & 927.76 & 923.9 & 921.97 & 923.9 & 923.9 \\
OH Hydrogen Bonded & $3200-3600$ & 3414 & 3448.72 & 3417.86 & 3415.93 & 3446.79 \\
C=C Alkenes & $1610-1680$ & 1647.21 & 1633.17 & 1629.85 & 1633.71 & 1627.92 \\
CO Esters & $1000-1300$ & 1016.49 & 1020.34 & 1020.34 & 1020.34 & 1020.34 \\
\hline
\end{tabular}

Edible film containing jackfruit seed starch, rosella flower extract, CMC, and glycerol has a combination of functional groups $\mathrm{CH}$ (Alkane), $\mathrm{CH}$ (Alkene), $\mathrm{OH}$ (Hydrogen Bonded Alcohol), $\mathrm{C}=\mathrm{C}$ (Alkene), $\mathrm{CO}$ (Ester). This functional group shows that edible film can be degraded and can be said to be an environmentally friendly plastic.

\subsection{4 $\mathrm{pH}$ test}

The edible film's $\mathrm{pH}$ was measured using a $\mathrm{pH}$ meter, with the aim of knowing the degree of acidity of the edible film. The results of the $\mathrm{pH}$ test can be seen in Table 1. Results The research in Table 3 shows that the addition of rosella flower extract can produce an acidic edible film $(\mathrm{pH}<7)$. The chemical reaction between the active compound of rosella flower and other ingredients makes the edible film produced has a lower $\mathrm{pH}$ than the edible starch of jackfruit seed without extract which has a pH of 6.651 [16]. Active compounds from rosella flowers such as anthocyanins, gossip tin, hibisci glucoside, vitamin $\mathrm{C}$ have the ability as antioxidants. Antioxidant compounds have high reactivity as hydrogen donors so that the hydrogen ion concentration in edible films becomes higher [18].

\subsubsection{Biodegradability test}

Biodegradation is the ability of bioplastics to decompose. The test results can be seen in Figure 4.

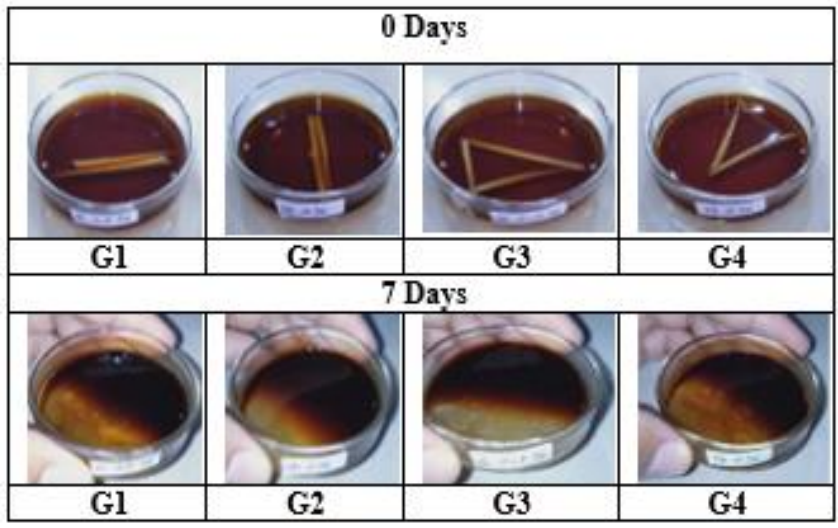

Figure 4. Edible film degradation

Results in Figure 4 show that the edible film of jackfruit seed starch with the addition of rosella flower extract 
decomposes or degrades completely in time. 7 days. This is because EM4 contains bacteria that can break polymer chains into monomers. These bacteria include fermenting bacteria from the genus Lactobacillus, photosynthetic bacteria actinomycetes, phosphate solubilizing bacteria and yeast [25].

Jackfruit seed starch is a natural polymer that is easily degraded by nature and other decaying bacteria. This is reinforced by research by Anggraeni, 2021 [8] which states that edible films made from jackfruit seed starch can be easily degraded by bacteria within 5 days. The addition of rosella flower extract can form a stronger edible intramolecular bond so as to increase the degradation time of the edible film. The edible film produced in this study proved to be environmentally friendly compared to synthetic plastics which had only been degraded for 50 years $[34,35]$.

\subsubsection{Water absorption}

The water absorption test aims to determine the percentage of water absorption from the edible film. The results of the water absorption test of edible film can be seen in Table 1 . The results in Table 1 show that the edible film with the addition of rosella flower extract is $1.5 \%, 2 \%, 2.5 \%$ and $3 \%(\mathrm{v} / \mathrm{v})$ have different water absorption capacity, respectively, namely $80 \%$, $70 \%, 60 \%$, and $61.67 \%$. The best water resistance was indicated by the lowest water absorption value, namely the addition of $2.5 \%(\mathrm{v} / \mathrm{v})$ extract. The addition of flower extracts can decrease the absorption of edible films, because it increases the intramolecular hydrogen bonds in the polymer films so that the structure is tighter and increases water resistance [18]. The thickness of the edible film is directly proportional to the ability of absorption, the thicker the product, the greater its absorption to water [26].

\subsubsection{Solubility test}

Solubility is a physical property that shows the percentage of dry weight dissolved after being immersed in water for 24 hours [27]. The results of the solubility test can be seen in Table 1.

The results in Table 1 show that the solubility of edible film with the addition of rosella flower extract is $1.5 \%, 2 \%, 2.5 \%$ and $3 \%(\mathrm{v} / \mathrm{v})$. different results were obtained, respectively, namely $100 \%, 41.67 \%, 17.65 \%$, and $40 \%$. The highest solubility value was obtained with the addition of $1.5 \%$ extract, while the lowest was obtained with the addition of $2.5 \%(\mathrm{v} / \mathrm{v})$ extract. The entire edible film material is hydrophilic (likes water), so that the edible film is more soluble in water. However, the addition of rosella flower extract can reduce the solubility of edible films, because phenolic compounds from rosella flowers can interact to form hydrogen bonds with other molecules [18]. The increasing hydrogen bonding causes the molecular structure to become more compact, thereby reducing the solubility of the film. Edible film that has a high solubility value will be easier to consume because it is easier to digest when the product is eaten [21].

\subsubsection{Water vapor transmission rate}

The water vapor transmission rate (WFTR) is the rate at which water vapor enters the edible film at a certain temperature and humidity [20]. The measurement results are then averaged to obtain the value of the water vapor transmission rate which can be seen in Table 1 .

The results in Table 1 show that the water vapor transmission rate of edible film with the addition of rosella flower extract is $1.5 \%, 2 \%, 2.5 \%$ and $3 \%(\mathrm{v} / \mathrm{v})$ the results were not much different, respectively, namely 0.6356 gram/hour.m², 0.61304 gram/hour.m² ${ }^{2} 0.6714$ gram/hour.m² ${ }^{2}$, 0.6775 grams/hour.m ${ }^{2}$. The best water vapor transmission rate was obtained by adding $2 \%$ extract. Increasing the concentration of the extract did not give a big difference to the water vapor transmission rate of each edible film. The factor that affects the transmission is thickness, where the thicker the edible film the tighter the structure, the stronger the ability to withstand gas migration and protect the product from physical damage [32].

This result has met the standard value of the water vapor transmission rate according to the Japanese Industrial Standards (1975), where the maximum value of the edible film water vapor transmission rate of 10 grams / 24 jam. ${ }^{2}[15,19]$. The low rate of water vapor transmission can inhibit the loss of water from the product thereby inhibiting product damage due to hydrolysis and damage to microorganisms due to the presence of water [36].

\subsubsection{Shelf life test}

The shelf life test was carried out by applying edible film to potato slices. The results of the shelf life test can be seen in Table 3.

The results in Table 3 show that potatoes wrapped in edible film at room temperature of $16^{\circ} \mathrm{C}$ can last for 8 days while at $30^{\circ} \mathrm{C}$ potatoes can last for 6 days. Potatoes wrapped in edible film last longer than potatoes that are not packaged and packaged with parchment paper. This indicates that edible film can increase the shelf life of potatoes. The edible film in this study had a longer shelf life than the edible film of jackfruit seed starch without the addition of extract which lasted for 6 days at $16^{\circ} \mathrm{C}$ and 4 days at $30^{\circ} \mathrm{C}[16]$. The addition of rosella flower extract can increase the shelf life of edible films because it contains antioxidants that can inhibit oxidation reactions that occur during the food storage process. Antioxidants are compounds that can prevent cells from damage caused by unstable molecules known as free radicals. Free radicals cause oxidative damage to lipids, proteins and nucleic acids. Antioxidant compounds will give up one or more electrons to free radicals so that they become normal molecular forms again and stop various damage caused [10].

Table 3. Shelf life test of edible film

\begin{tabular}{ccccc}
\hline No & Application to Potatoes & Room Temperature $\left({ }^{\circ} \mathbf{C}\right)$ & Life (days) & Physical Condition \\
\hline 1 & Wrapped with Edible film & 16 & 8 & Good, slightly shriveled, not blackened and not moldy \\
2 & Unpackaged & 16 & 4 & wrinkled and slightly darkened \\
3 & Wrapped with Edible film & 30 & 6 & Slightly wrinkled, not moldy and slightly blackened \\
4 & Wrapped with parchment paper & 30 & 3 & Wrinkled, slightly moldy and slightly blackened \\
5 & Without packaging & 30 & 2 & Wrinkled, slightly moldy and slightly blackened \\
\hline
\end{tabular}




\subsubsection{Analysis of antioxidant activity with DPPH method}

Antioxidant activity test aims to determine the antioxidant activity content of edible film added rosella flower extract. Measurement of antioxidant activity using the DPPH $(1,1-$ diphenyl-2-picrylhydrazyl) method with UV-Vis spectrophotometry at a wavelength of $517 \mathrm{~nm} \mathrm{[30].} \mathrm{DPPH} \mathrm{is}$ an organic compound containing unstable nitrogen and will change color (purple to yellow) after being reduced by antioxidant compounds [37]. The amount of antioxidant activity is indicated by the $\mathrm{IC}_{50}$ value, namely the concentration of the extract which is able to inhibit the activity of a radical by $50 \%$. The $\mathrm{IC}_{50}$ value was determined using a linear regression equation from the relationship curve of the sample concentration to the percent inhibition with the equation $\mathrm{y}=\mathrm{ax}+\mathrm{b}$, the sample concentration (ppm) as the $\mathrm{x}$ axis and the percent inhibition value as the y-axis. Percent inhibition is an antioxidant activity of edible film based on the amount of DPPH radical absorption barrier [30]. The linear regression equations of each edible film can be seen in Figure 5 .

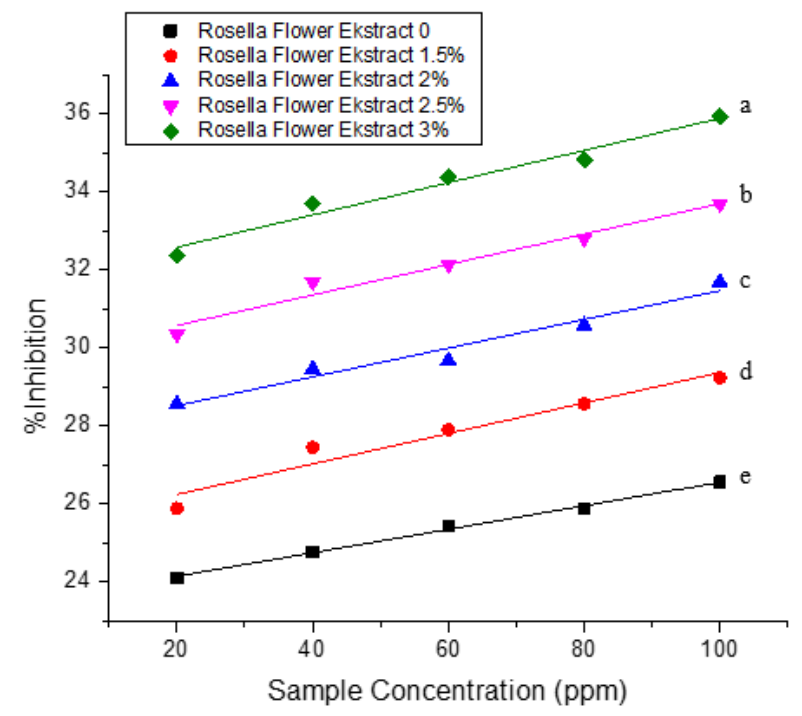

Figure 5. Percentage inhibition curve of edible film without adding rosella flower extract (a) with addition of $1.5 \%$ (b) $2 \%$ (b) $2.5 \%$ (c) $2.5 \%$ (d) and $3 \%$ (e) rosella flower extract

Based on the equation linear regression in the figure above, the $\mathrm{IC}_{50}$ value is obtained which can be seen in Table 4 .

Table 4. Edible film $\mathrm{IC}_{50}$ value

\begin{tabular}{cc}
\hline Edible Film Sample & IC $_{\mathbf{5 0}}$ Value (ppm) \\
\hline G0 & 267.264 \\
G1 & 246.244 \\
G2 & 241.801 \\
G3 & 236.145 \\
G4 & 219.948 \\
\hline
\end{tabular}

The results in Table 4 show that the activity The antioxidant of edible film increased along with the addition of rosella flower extract concentration. The highest antioxidant activity is found in edible films with the addition of $3 \%(\mathrm{v} / \mathrm{v})$ extract which has an $\mathrm{IC}_{50}$ value of $219.948 \mathrm{ppm}$. The smaller the $\mathrm{IC}_{50}$ value, the greater the potential for antioxidant activity [38]. Antioxidant activity is said to be very strong if it has $\mathrm{IC}_{50}<50$ ppm, strong antioxidants have $\mathrm{IC}_{50}$ values between $50-100$ ppm, moderate antioxidants have $\mathrm{IC}_{50}$ values between $100-150$ ppm, weak antioxidants have $\mathrm{IC}_{50}$ values between 150-200 ppm and very weak antioxidant has $\mathrm{IC}_{50}>200 \mathrm{ppm}$. From the measurement results, the edible film in this study has very weak antioxidants because it has $\mathrm{IC}_{50}>200 \mathrm{ppm}$.

The edible film of jackfruit seed starch without the addition of rosella flower extract already contains antioxidant compounds characterized by an $\mathrm{IC}_{50}$ value of $267.264 \mathrm{ppm}$. The results of this study are in line with the results of research from Chai et al. [39] which stated that the protein isolated from jackfruit seeds had potential as an antioxidant. The use of jackfruit seed starch as an encapsulation material has been investigated by Patel et al. [40] and was found to have antioxidant activity. The addition of rosella flower extract increased the antioxidant content of the edible film of jackfruit seed starch. This is influenced by the flavonoid compounds contained in rosella flowers. Flavonoid compounds are polyphenol components found in many plants. Flavonoids can act as antioxidant compounds by releasing hydrogen atoms from their hydroxyl groups and binding to free radicals (ROS/Reactive Oxygen Species or RNS/Reactive Nitrogen Species) until they are neutrally charged. Stable free radicals will stop carrying out chain reactions so as to prevent damage to lipids, proteins, or DNA $[15,19]$. It can be said that the addition of rosella flower extract enhances another benefit of edible film which functions as a food protector from the oxidation process and counteracts free radicals.

\section{CONCLUSION}

The addition of rosella flower extract to the edible film is directly proportional to elongation, water vapor transmission rate, and antioxidant activity, according to the physical and chemical characteristics of the edible film of jackfruit seed starch with the addition of rosella flower extract. Water absorption and solubility are inversely proportional. The more the amount of rosella flower extract added, the higher the thickness, tensile strength, elasticity, and $\mathrm{pH}$ will initially be, but under specific conditions, or when the saturation point is reached, both parameters will decrease.

The best treatment in this study was jackfruit seed edible film with the addition of rosella flower extract $2 \%(\mathrm{v} / \mathrm{v})$ with the results obtained for each thickness of $0.09 \mathrm{~mm}$, tensile strength of $0.003332 \mathrm{~N} / \mathrm{mm}^{2}$, elongation percentage $126.36 \%$, elasticity $0.002637 \mathrm{Kgf} / \mathrm{mm}^{2}$, $\mathrm{pH}$ 6.122, water absorption $61.67 \%$, solubility $40 \%$, water vapor transmission speed 0.6714 gram/hour $\mathrm{m}^{2}$, FTIR test results show that the process of making edible film in this research is the process of mixing of Physics, edible film shelf life at room temperature is 6 days and at cold temperatures was 8 days, and have antioxidant activity with $\mathrm{IC}_{50}$ values $219.948 \mathrm{ppm}$.

\section{ACKNOWLEDGMENT}

The authors acknowledge the Laboratory of Minerals and Advanced Materials, State University of Malang and the Integrated Laboratory of Hasanuddin University.

\section{REFERENCES}

[1] Ahmad, A.F., Maflahah, I., Rahman, A. (2016). Pengaruh jenis pengemas dan lama penyimpanan 
terhadap mutu produk nugget gembus. AGROINTEK, 10(2): 70-75. https://doi.org/10.21107/agrointek.v10i2.2468

[2] Huri, D., Fithri, C.N. (2014). Pengaruh konsentrasi gliserol dan ekstrak ampas kulit apel terhadap kharakteristik fisik dan kimia edible film. Jurnal Pangan Dan Agroindustri, 2(4): 29-40.

[3] Ilmiahwati, C., Reza, M., Rahmatini, R., Rustam, E. (2017). Edukasi pemakaian plastik sebagai kemasan makanan dan minuman serta risikonya terhadap kesehatan pada komunitas di Kecamatan Bungus Teluk Kabung, Padang. Jurnal Ilmiah Pengabdian Kepada Masyarakat, 1(1): 20-28. https://doi.org/10.25077/logista.1.1.20-28.2017

[4] Surotono, U.B., Ismanto. (2016). Pengolahan sampah plastik jenis PP, PET dan PE menjadi bahan bakar minyak dan karakteristiknya. Jurnal Mekanika dan Sistem Termal, 1(1): 32-37.

[5] Murni, S.W., Pawignyo, H., Widyawati, D., Sari, N. (2013). Pembuatan edible film dari tepung jagung (Zea Mays L.) dan kitosan. Prosiding Seminar Nasional Teknik Kimia, 1-9.

[6] Fatimah, C., Marpongahtun, Z. (2013). PhysicalMechanical properties and microstructure of breadfruit starch edible films with various plasticizer. EKSAKTA, 13(1): $57-61$ https://doi.org/10.20885/eksakta.vol13.iss1-2.art7

[7] Ranasinghe, R.A.S.N., Maduwanthi, S.D.T., Marapana, R.A.U.J. (2019). Nutritional and health benefits of jackfruit (Artocarpus heterophyllus Lam.): A review. International Journal of Food Science. https://doi.org/10.1155/2019/4327183

[8] Mushumbusi, D.G. (2015). Production and characterization of Jackfruit jam (Doctoral dissertation, Sokoine University of Agriculture). http://www.suaire.sua.ac.tz/handle/123456789/1203.

[9] Manuhara, G.J., Kawiji, K., Heny Ratri, E. (2009). Aplikasi edible film maizena dengan penambahan ekstrak jahe sebagai antioksidan alami pada coating sosis sapi. Jurnal Teknologi Hasil Pertanian, 2(2): 50-58. https://doi.org/10.20961/jthp.v0i0.12868

[10] Djaeni, M., Ariani, N., Hidayat, R., Utari, F.D. (2017). Ekstraksi antosianin dari kelopak bunga rosella (Hibiscus sabdariffa L.) berbantu ultrasonik: Tinjauan Aktivitas Antioksidan. Jurnal Aplikasi Teknologi Pangan, 6(3): 148-151. http://dx.doi.org/10.17728/jatp.236

[11] Nopiyanti, V., Harjanti, R. (2016). Analisis stabilitas senyawa aktif antioksidan kelopak bunga rosella ( Hibiscus sabdariffa L.) pada penggunaannya sebagai bahan tambahan pangan alami. Jurnal Farmasi Indonesia, 13(2): 101-110.

[12] Rahmawati, S., Aulia, A., Hasfah, N., Nuryanti, S., Abram, P.H., Ningsih, P. (2021). The Utilization of Durian Seeds (Durio Zibethinus Murr) as a Base for Making Edible Film. International Jurnal of Design \& Nature and Ecodynamics, 16(1): 77-84 https://doi.org/10.18280/ijdne.160110

[13] Rahmawati, S., Aulia, A., Nuryanti, S., Suherman. (2020). The making and characterization of Banggai Tuber (Dioscorea Spp) edible film. International Journal of Advanced Science and Technology, 29(05): 81418153.

http://sersc.org/journals/index.php/IJAST/article/view/1 8462.
[14] Fatisa, Y., Agustin, N. (2018). Characterization and antioxidant activity edible film of durian (Durio zibethinus) seed starch with the addition of soursop (Annona muricata L.) leaf. Indonesian Journal of Chemical Science and Technology State University of Medan, 1(1): 37-42. https://doi.org/10.24114/ijcst.v1i1.10200

[15] Anggraeni, P. (2021). Pembuatan dan karakterisasi edible film dari biji Nangka (Artocarpus heterophyllus L.). Skripsi, Universitas Tadulako. Palu.

[16] Sumarni, N.K., Puspitasari, D.J., Sulastri, E., Rahim, E.A., Mauru, Y.S. (2019). Microcapsule efficiency of ethanol extract of rosella petal flower (hibiscus sabdariffa linn) coated crude carrageenan (Eucheuma cottony). In Journal of Physics: Conference Series, 1280(2): 022074. https://doi.org/10.1088/1742$6596 / 1280 / 2 / 022074$

[17] Sedyadi, E., Aini, S.K., Anggraini, D., Ekawati, D.P. (2016). Starch-glycerol based edible film and effect of rosella (hibiscus sabdariffa linn) extract and surimi dumbo catfish (clarias gariepinus) addition on its mechanical properties. Biology, Medicine, \& Natural Product Chemistry, 5(2): 33-40. https://doi.org/10.14421/biomedich.2016.52.33-40

[18] Paristiowati, M., Moersilah, M., Stephanie, M.M., Zulmanelis, Z., Idroes, R., Puspita, R.A. (2019). Rosa SP and Hibiscus sabdariffa $\mathrm{L}$ extract in ethanol fraction as acid base indicator: Application of green chemistry in education. In Journal of Physics: Conference Series, 1402(5): $\quad 055041 . \quad$ http://dx.doi.org/10.1088/1742$6596 / 1402 / 5 / 055041$

[19] Zhang, P., Zhao, Y., Shi, Q. (2016). Characterization of a novel edible film based on gum ghatti: Effect of plasticizer type and concentration. Carbohydrate Polymers, 153: 345-355. https://doi.org/10.1016/j.carbpol.2016.07.082

[20] Kurt, A., Kahyaoglu, T. (2014). Characterization of a new biodegradable edible film made from salep glucomannan. Carbohydrate Polymers, 104: 50-58. https://doi.org/10.1016/j.carbpol.2014.01.003

[21] Aisyah, Y., Irwanda, L.P., Haryani, S., Safriani, N. (2018). Characterization of corn starch-based edible film incorporated with nutmeg oil nanoemulsion. In IOP Conference Series: Materials Science and Engineering, 352(1): $\quad 012050 . \quad$ https://doi.org/10.1088/1757$899 X / 352 / 1 / 012050$

[22] Thakur, R., Saberi, B., Pristijono, P., Golding, J., Stathopoulos, C., Scarlett, C., Bowyer, M., Vuong, Q. (2016). Characterization of rice starch-1-carrageenan biodegradable edible film. Effect of stearic acid on the film properties. International Journal of Biological Macromolecules, 93: 952-960. https://doi.org/10.1016/j.ijbiomac.2016.09.053

[23] Jouki, M., Khazaei, N., Ghasemlou, M., HadiNezhad, M. (2013). Effect of glycerol concentration on edible film production from cress seed carbohydrate gum. Carbohydrate $\quad$ Polymers, 96(1): 39-46. https://doi.org/10.1016/j.carbpol.2013.03.077

[24] Miksusanti, M., Herlina, H., Masril, K.M.K. (2013). Antibacterial and antioxidant of UWI (Dioscorea alata L) starch edible film incorporated with ginger essential oil. International Journal of Bioscience, Biochemisty and Bioinformatics, 3(4): 354-356.

[25] Setiani, W., Sudiarti, T., Rahmidar, L. (2013). 
Preparation and characterization of edible films from polunlend pati sukun-kitosan. Valensi, 3(2): 100-109. https://doi.org/10.1680/jbibn.20.00010

[26] Vicentini, N.M., Dupuy, N., Leitzelman, M., Cereda, M.P., Sobral, P.J.A. (2005). Prediction of cassava starch edible film properties by chemometric analysis of infrared spectra. Spectroscopy Letters, 38(6): 749-767. https://doi.org/10.1080/00387010500316080

[27] Shreepathi, S., Naik, S.M., Vattipalli, M.R. (2012). Water transportation through organic coatings: correlation between electrochemical impedance measurements, gravimetry, and water vapor permeability. Journal of Coatings Technology and Research, 9(4): 411-422. https://doi.org/10.1007/s11998-011-9376-4

[28] Saraiva, L.E.F., Naponucena, L.D.O.M., da Silva Santos, V., Silva, R.P.D., de Souza, C.O., Souza, I.E.G.L., Mamede, M.E.O., Druzian, J.I. (2016). Development and application of edible film of active potato starch to extend mini panettone shelf life. LWT, 73: 311-319. https://doi.org/10.1016/j.lwt.2016.05.047

[29] Ruan, C., Zhang, Y., Wang, J., Sun, Y., Gao, X., Xiong, G., Liang, J. (2019). Preparation and antioxidant activity of sodium alginate and carboxymethyl cellulose edible films with epigallocatechin gallate. International Journal of Biological Macromolecules, 134: 1038-1044. https://doi.org/10.1016/j.ijbiomac.2019.05.143

[30] Di Pierro, P., Chico, B., Villalonga, R., Mariniello, L., Damiao, A.E., Masi, P., Porta, R. (2006). Chitosanwhey protein edible films produced in the absence or presence of transglutaminase: Analysis of their mechanical and barrier properties. Biomacromolecules, 7(3): 744-749. https://doi.org/10.1021/bm050661u

[31] Ramos, O.L., Fernandes, J.C., Silva, S.I., Pintado, M.E., Malcata, F.X. (2012). Edible films and coatings from whey proteins: A review on formulation, and on mechanical and bioactive properties. Critical Reviews in Food Science and Nutrition, 52(6): 533-552. https://doi.org/10.1080/10408398.2010.500528

[32] Monjazeb Marvdashti, L., Yavarmanesh, M., Koocheki, A. (2016). The effect of different concentrations of glycerol on properties of blend films based on polyvinyl alcohol-allysumhomolocarpum seed gum. Iranian Journal Food Science and Technology Research, 12(5): 663-677.

[33] Skoog, D.A., Holler, F.J., Crouch, S.R. (1998). Principles of Instrumental Analysis. Cengage Learning, 837-847.

[34] Shit, S.C., Shah, P.M. (2014). Edible polymers: Challenges and opportunities. Journal of Polymers. https://doi.org/10.1155/2014/427259

[35] Rhim, J.W., Park, H.M., Ha, C.S. (2013). Bionanocomposites for food packaging applications. Progress in Polymer Science, 38(10-11): 1629-1652. https://doi.org/10.1016/j.progpolymsci.2013.05.008

[36] Pyrzynska, K., Pękal, A. (2013). Application of free radical diphenylpicrylhydrazyl (DPPH) to estimate the antioxidant capacity of food samples. Analytical Methods, 5(17): 4288-4295. http://dx.doi.org/10.1039/C3AY40367J

[37] Molyneux, P. (2003). The use of the stable free radical diphenylpicryl- hydrazyl (DPPH) for estimating antioxidant activity. Songklanakarin Journal of Science and Technology, 26(2): 211-219.

[38] Barros, R.G.C., Andrade, J.K.S., Denadai, M., Nunes, M.L., Narain, N. (2017). Evaluation of bioactive compounds potential and antioxidant activity in some Brazilian exotic fruit residues. Food Research International, 102: 84-92. https://doi.org/10.1016/j.foodres.2017.09.082

[39] Chai, T.T., Xiao, J., Dass, S.M., Teoh, J.Y., Ee, K.Y., Ng, W.J., Wong, F.C. (2021). Identification of antioxidant peptides derived from tropical jackfruit seed and investigation of the stability profiles. Food Chemistry, 340: 127876 . https://doi.org/10.1016/j.foodchem.2020.127876

[40] Patel, A.S., Kar, A., Mohapatra, D. (2020). Development of microencapsulated anthocyanin-rich powder using soy protein isolate, jackfruit seed starch and an emulsifier (NBRE-15) as encapsulating materials. Scientific Reports, 10(1): 1-12. https://doi.org/10.1038/s41598020-67191-3 